座長 平田良昭 (旭川医科大学附属病院)

6. FCRによるリニアックグラフィーの検村

○小島 洋・野䗁裕之・伊藤英樹（日鋼記念病院）

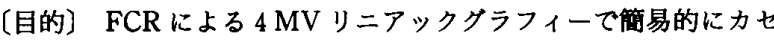
ッテの中に金属板をはさむことで，良好な画像作成を試みた。

〔方法〕1．金属板付加による増感効果を調べる。

2. 頭部ファントム・臨床での FCR リニアックグラフィ 一を評価する。

【結果〕1. IP 前面に1.5 2.0 $\mathrm{mm}$ の $\mathrm{Al}$ 又は $\mathrm{Cu}+\mathrm{Al}$ 付加て，約 $20 \%$ 増感効果があった。

2. IP 後面に $0.5 \mathrm{~mm} \mathrm{Cu}$ 付加で, カセッテ後方散乱アー チファクトを除去できた。

3. 頭部ファントム・臨休のリニアックグラフィーでは, FCR 周波数処理エッジ強調画像は, 従来の画像フィル ムスクリーン系よりも照射野照合し易くなった。

\section{7. 移㲜客台を用いた全身照射方法の模期}

藤田勝久・古家輝夫・渡辺良晴・山口 恵（北大病院）

全身照射は骨随移植の前処理として重要な役割を果たしており,当 施設でもこれまでに約30例の照射が行われている. 今回, 移動型寝台 を用いた照射方法の内容や線量測定の結果を示すとともに, 移植後の 経過から本法の評価を行なった。

使用した床置き型移動寝台はパソコンで制御され,任意の設定区間 内において移動速度を変更することができる，治療のための基砋デー 夕の測定では, ファントム中の線量は檪台移動方向で士0.5\%の均等 度を示し, ベット移動速度に反比例し, 治愎装置の線量率に比例し た。計算に使用する深部量百分率は実際の照射位㯰で, 移動した状態 で剆定したデータを使用し，このときの基準点での積算線量，照射 野，移動速度，線量率を基本テーブルとし，患者体厚により個々の補 正を行なった。

照射は 1 回 $2.0 \mathrm{~Gy}$ を A-P, P-A のそれそれ 2 scanで行ない, 照射 野 $30 \times 10$ (移動方向) $\mathrm{cm}$ (at SSD = $100 \mathrm{~cm}$ ), 移動速度 $5 \mathrm{~mm} / \mathrm{s}$, 線 量率 $50 \mathrm{cGy} / \mathrm{min}$ で行なった. 患者の治療時に TLDを用いて 8 部位 での線量の確認を行った結果, 体厚の補正を移動速度で行なうことで 不均等度は最大で約 $7 \%$ 以内になった。肺の遮蔽は線量を $2 / 3$ に減 らすため厚さ $1 \mathrm{~cm}$ の鉛を用い,リニアックグラフィーにより形状を 型取り, 皮间間距離 $10 \mathrm{~cm}$ のところで使用した。水晶体の遮蔽は $\mathrm{A}-\mathrm{P}$ 照射時に, 高さ $2 \mathrm{~cm}$ 直径 $1.5 \mathrm{~cm}$ の鉛を距離 $15 \mathrm{~cm}$ のところで使用 した.

この照射方法は患者は仰臥位または伏卧位で寝ているだけで良い ため負担が少なく，肺や眼の遮蔽も比較的容易に再現性良くすること ができる，また，移植後の経過に放射線が原因と思われる間質性肺 炎, 再発等はみられなかった。

今後の課題として, 線量の精度と安全性のため, 治療装置の線量率 とベットの移動速度の間に何らかのフィードバック機構が必要であ る.

8. 放射線治療システムの精度管理〜CT シュミレーターに於ける 粗度の検时〜

○桑原 智・秦野敦史・高地宏修・我妻武士・下川良美 太田洋一・栗田政一（帯広厚生病院放）

放射線治療に於いて, 治療計画は照射部位, 照射方法を決める過程 として重要である。従来は，X線シュミレーターを用いて治療部位の 決定を行ってきたが, 近年, CT 装置が放射線治療計画のシステムの 1つとして，䓕入されてきている. CT シュミレーターは target volume の把暒の精度がすぐれている為, 治療ビームを集束させ容積効 果を利用した質の高い治療が可能となった。

我々の施設では, CT シュミレーター (CTS-20X) が導入され 1年 半が経過している. 今回, 治療精度の向上の為, 投光器やべットなど の各個別の可動精度及びシステム全体の精度の検討を行った.

その結果，投光器やベットの可動精度及びシステム全体の精度は土 $0.5 \mathrm{~mm}$ 以内の鿁差であった。現在, 投光器の精度管理として定期的 $に$ iso center の check を行っている.

\section{座長集約}

演題 6 はFCR により治療部位の照合を行うものである. 高エネル
ギー領域における FCR のパラメーターや画像処理技術を確立して 性能を最大限引き出すことにより，正確な照合が可能になると考え 了.

所問 藤田学園の報告では照射野が鉛ブロックによりトリミング されている場合は処理方法を変更したほうが良いということである が，その点について検討しているか.

答 周波数エッジ強調の度合によって,辺縁が淮やける事があるよ うで, 今後の検討課題としたい.

留同 ブロックの辺緣をエッジ強調したとき実際の治療部位と照 合写真の照射野が一致しないことがあるので検討をお願いしたい。

答了解.

演題 7 は全身照射をパソコン制御の移動寝台でおこなうものであ ろ. 投与線量の精度が保証されるならば，この方法が患者にとっては 一番負担のかからない治療法であり, 個別の基本デー夕取得の重要性 を痛感した。

姵 TPR データ取得のための線量湘定の際，線量計の位置はど のようにしたか.

答 実際の治療に近づける意味で STD185 cm で行った。

成成したTPR データが通常より高くなった原因は何故か。 答 ピーク深の 2.5 ないし $3 \mathrm{~cm}$ の平坦な部分の線量が低かった事 で深い部分の線量が上がったと考えている.

杽 ベッドの移動により放射線場が一様に照射されていない事 から，置換係数やその他の係数が変化したことによると思われるがそ れについてはどうか。

答 その可能性もある.

㚱同 線量測定には $0.6 \mathrm{cc}$ のチャンバーだけの使用ではなくて, 他 の測定器を併用したほうがよいのではないか。

答 照射野の辺緑をなぞるのでその付近ではチャンバーの大きさ は問題になると思う。

演題 8 はCT シュミレーターの精度管理についてシステムの運用 を $00.5 \%$ 以内で行っているというものである. 近年ステレオ照射等, 非常に高精度のプランニングが要求されるに伴い, 装置の QC, QA の 比重は益々高まるであろう。

間この精度により治療全体の不確定度はどのくらい向上した か.

答 今回はRTCTについてのみ行った. 今後, 総合的にシステム 全体の精度を求めて行きたい。

座長 阿渡加正弘（岩見沢労災病院）

9.呼吸補正を用いた Portral MR-angiograpy 小田原好宏・板東道夫・鎌形政樹・坂田元道 （札幌医科大学医学部附属病院）

〔目的〕門脈情報に注目し， 2 次元収集画像から良好な 3 次元表示 の再構成門脈像を得る方法を検討する。

〔方法〕1. Portal MRA に必要な項目を挙げ，項目別に適する撮 影手法を選択し，適する撮影法を検討する。

2. 本法と従来の息止めによる $2 \mathrm{D}-\mathrm{TOF}$ 法を比較検討す 了.

〔結果〕1，撮影法の検討から呼吸補正を用いた Multplanar GRASS 法を MRA に応用した。

2. 本法は従来の息止めによる2D-TOF 法と比較し，3D 表示画像の連続性, 肝内門脈の描出の両面で有用であっ た.

10. MR angiography による心・血管系及ひ眠动眽の描出について 真壁武司・村屋 保・橋本泰弘・田井中恵一・三上 仁 越中谷伸一（市立函館病院）

(目的〕 MRAにより心・血管系，肺動脈について適当と思われる いくつかの方法を施行しそれそれれの撮像法に対し描出能について比 較検討した。

(方法) 使用装置は SIEMENS 社 Impact (超伝導 $1.0 \mathrm{~T}$ ), 使用 coil は bodycoil で coronal 方向にて FOV450 mm で比較した。撮像 はFLASH シーケンスによる2D-Time of Flight 法による息止め撮 像, 息止め無しに連続で撮像する方法, 更に心電図同期により撮像す る方法を施行した。 同様に 3D-Time of Flight 法について, 息止めと 